Short Communication

\section{ALTERATION OF CATECHOLAMINE METABOLISM IN RAT BRAIN PRODUCED BY INHALATION EXPOSURE TO METHYL BROMIDE}

$$
\begin{gathered}
\text { 臭化メチル吸入暴露によるラット脳内 } \\
\text { カテニラミン代謝の变化 }
\end{gathered}
$$

Key words: methyl bromide; norepinephrine; 3methoxy-4-hydroxyphenylglycol; tyrosine hydroxylase; DOPA; HPLC; native fluorescence.

Methyl bromide $\left(\mathrm{CH}_{8} \mathrm{Br}\right.$ : $\left.\mathrm{MB}\right)$ exerts a neurotoxic effects on human beings ${ }^{1)}$ and experimental animals. $^{2}{ }^{3)}$ To evaluate the toxicity of $\mathrm{MB}$, we exposed rats to $M B$ gas and investigated the neurochemical changes in discrete brain areas. ${ }^{4,5)}$ Microanalysis of monoamines demonstrated changes in brain levels of catecholamine and metabolites. 5 ) In our previous study, ${ }^{8)}$ an $8-\mathrm{h}$ exposure of rats to $125 \mathrm{ppm} \mathrm{MB}$ produced a drop of body temperature and inhibition of food intake. Hyperthermia and anorexia were occasionally observed in $\mathrm{MB}$ intoxicated patients. Nerve cells which regulate body temperature and appetite are known to be located in hypothalamus. In the present study, we investigated MB-induced changes of catecholamine metabolism in hypothalamus and mode of inhibition of tyrosine hydroxylase (TH) activity in rat brain following a single exposure. A new assay system was introduced for measurement of TH activity.

Methods. Groups of male SD rats (Charles River Japan), 250 to $300 \mathrm{~g}$ in body weight, were exposed to MB gas for $8 \mathrm{~h}$ from 6:00 a.m. Procedures for exposure have been described previously.4) Following the exposure, rat head used for measurement of catecholamine contents was irradiated by microwave power $(4.6 \mathrm{~kW}, 1.9 \mathrm{~s})$ and decapitated. Rat subjected to estimaion of TH activity was killed by decapitation. Brain was dissected and stored at $-80^{\circ} \mathrm{C}$. $)$ Procedures of quantitation of catecholamine and metabolite with HPLC have been described previously.6) TH activity was measured as follows. Hypothalamus was homogenized in Tris buffer, $\mathrm{pH}$ 7.25 , containing sucrose and Triton $\mathrm{X}-100$. Reaction medium was mixed with substrate, Ltyrosine (D-tyrosine for control) solution. The reaction medium contained 6-methyl-5,6,7,8-tetra- hydropterine (1.2 $\mathrm{mM}$ in final concentration), mercaptoethanol (final $90 \mathrm{~mm}$ ), catalase 300 units, NSD-1015 (decarboxylase inhibitor, final $100 \mu \mathrm{M}$ ), and acetate buffer, pH 6.1 (final $0.4 \mathrm{M}$ ). The reaction was started by adding homogenate. Following incubation for $20 \mathrm{~min}$ at $37^{\circ} \mathrm{C}$, reaction was stopped by adding $\mathrm{HClO}_{4}$ solution. Addition of EDTA, acetate buffer, pH 6.1, and $a$-methyl DOPA (internal standard) was followed by $\mathrm{K}_{2} \mathrm{CO}_{3}$ solution to adjust $\mathrm{pH}$ to 5-7. The solution was freezed overnight and centrifuged. DOPA in the supernatant formed by the enzyme reaction was extracted and purified by passing through Amberlite CG-50 column and adsorption on alumina. DOPA was liberated from alumina with $\mathrm{HCl}$ solution. HPLC procedures have been previously described. ${ }^{6)}$ Mobile phase used was $\mathrm{Na}_{2}-\mathrm{HPO}_{4}$-citrate buffer, $\mathrm{pH} 4.00$, containing EDTA, 1-octanesulfonate, and methanol. DOPA and a-methyl-DOPA were detected by measuring native fluorescence.6)

Results and discussion. In the present new detection system of DOPA, a linear relationship was observed between fluorescence intensity and amounts of DOPA (and $\alpha$-methyl DOPA) ranging widely from 1 to 800 pmoles. In a previous assay procedure, DOPA was detected by an electrochemical detector The sensitivity of the present assay system was comparable to the electrochemical detector. ${ }^{6)}$ Rats were exposed to $16,31,63,125,188$, or $250 \mathrm{ppm} \mathrm{MB}$ for $8 \mathrm{~h}$ and sacrificed immediately after exposure.

$\mathrm{NE}$ in hypothalamus was reduced by $\mathrm{MB}$ exposure in an $\mathrm{MB}$ concentration dependent manner (Fig. 1). Exposure at 16 ppm produced no significant change in NE content (data not shown). Percent decrease compared to control was $13 \%$ at $31 \mathrm{ppm}$ and $30 \%$ at $250 \mathrm{ppm}$. NE decrease after 8-h exposure at $250 \mathrm{ppm}$ was similar to that after $24-\mathrm{h}$ exposure at $100 \mathrm{ppm}$ $(29 \%)$ as reported previously.4) 3-Methoxy-4 hydroxyphenylglycol (MHPG), metabolite of NE, was increased by exposure. Percent increase compared to control was $34 \%$ at $250 \mathrm{ppm}$.

TH catalyzes hydroxylation of tyrosine to DOPA. NE, a principal neurotransmitter in the brain, is synthesized from tyrosine via DOPA and dopamine. Synthesis of DOPA is a rate limiting step in these serial reactions. Hypothalamus is known to be an NE neuron-rich region in the brain. TH activity of tissue homogenate was 


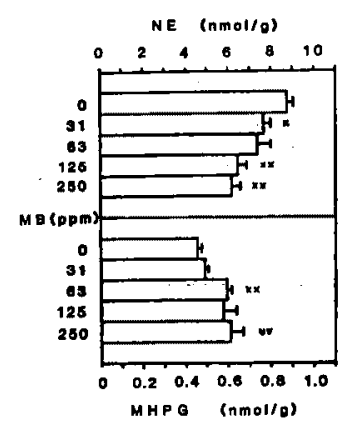

Fig. 1. Effects of MB on NE and MHPG levels in rat hypothalamus. Mean $\pm \mathrm{SE}(n=5) . \mathrm{x}: p<0.05$, $\mathrm{xx}: p<0.01$ by $t$-test. uv: Variances of control and exposed groups were unequal. Statistical significance was not observed by Aspin-Welch method.

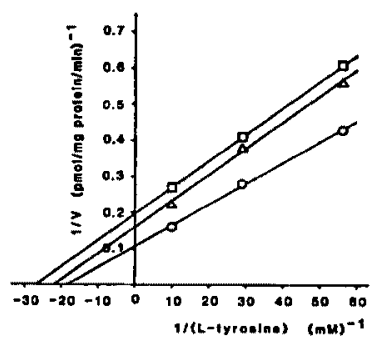

Fig. 2. Lineweaver-Burk plots of TH activity of hypothalamus homogenate of rats exposed to MB. TH activity was determined in triplicate in each point. $O:$ control, $\triangle: 63 \mathrm{ppm}, \square: 250 \mathrm{ppm}$.

measured at substrate concentrations of 18,35 , and $100 \mu \mathrm{M}$. At each substrate concentration, TH activity of exposed rat was lowered. From the Lineweaver-Burk plots, inhibition of $\mathrm{TH}$ activity by MB seems to be a mixed type of noncompetitive and uncompetitive inhibition (Fig. 2). Maximum velocity and Michaelis constant obtained at each exposure concentration are shown in Table 1. $\mathrm{Vm}$ and $\mathrm{Km}$ values at $250 \mathrm{ppm}$ were $54 \%$ and $67 \%$, respectively, compared with the control. These data suggest that a conformational change or a modification of enzyme molecule have occurred in TH of hypothalamus by $\mathrm{MB}$ exposure. $\mathrm{Vm}$ and $\mathrm{Km}$ values at 16 ppm were similar to control values. At $31 \mathrm{ppm}$, however, apparent reduction in these parameters was observed. NE reduction at $31 \mathrm{ppm} \mathrm{MB}$ was statistically significant. Lowered NE level in hypothalamus seems to be elicited, at least partly, by the inhibition of TH.
Table 1. Maximum velocity $(\mathrm{Vm})$ and Michaelis constant $(\mathrm{Km})$ of $\mathrm{TH}$ activity of hypothalamus homogenate.

\begin{tabular}{ccccccc}
\hline $\begin{array}{c}\text { MB concentra- } \\
\text { tion (ppm) }\end{array}$ & 0 & 16 & 31 & 63 & 125 & 250 \\
$\begin{array}{c}\text { Vm (pmol/mg } \\
\text { protein/min) }\end{array}$ & 9.4 & 9.3 & 5.8 & 6.3 & 5.9 & 5.1 \\
$\mathrm{Km}(\mathrm{mM})$ & 0.055 & 0.064 & 0.040 & 0.042 & 0.049 & 0.037 \\
\hline
\end{tabular}

Increase of MHPG by MB exposure may be the results of inhibition of $\mathrm{MHPG}$ elimination from synaptic areas.

Inhibition of NE synthesis (and fall in activity of NE neuron) in hypothalamus is likely to be the background of the changes of body temperature and appetite observed in clinical cases and experimental animals. More attention should be paid to nervous functions which are deeply related to hypothalamus, e.g. autonomic nervous system, in MB toxicity.

In this study, we observed an efficacy of kinetic analysis in toxicity evaluation. Further detailed study of alteration of catecholamine metabolism should be made to investigate the neurotoxicity of MB.

\section{REFERENCES}

1) Araki S, Ushio $K$, Suwa $K$, et al. Methyl bromide poisoning: a report based on fourteen cases. Jpn $\mathrm{J}$ Ind Health $1971 ; 13: 507-513$.

2) Ikeda T, Kishi $R$, Yamamura $K$, et al. Behavioural effects in rats following repeated exposure to methyl bromide. Toxicol Lett 1980; 6: 293-299.

3) Honma $T$, Miyagawa $M$, Sato $M$, Hasegawa $H$. Neurotoxicity and metabolism of methyl bromide in rats. Toxicol Appl Pharmacol 1985; 81: 183-191.

4) Honma $T$, Sudo A, Miyagawa $M$, et al. Significant changes in monoamines in rat brain induced by exposure to methyl bromide. Neurobehav Toxicol Teratol 1982; 4: 521-524.

5) Honma T, Hasegawa H. Depression of unconditioned behaviour and increase in catecholamine metabolites in the brain after a short-term exposure of rats to methyl bromide. J pn JPharmacol 1983; $33: 228$.

6) Honma T. Comparative study of fluorometric and electrochemical detection of catecholamine, serotonin, and metabolites in rat brain by highperformance liquid chromatography. Anal Lett 1986; $19: 417-431$.

Takeshi HonmA

National Institute of Industrial Health, Nagao 6-21-1, Tama-ku, Kawasaki, 214 Japan

本間健凟

学㗢省産業医学棇合研究所

Received for publication, September 8, 1986

Reprint requests to T. Honma, 通信先 : 本間あて 